\title{
Impact of reflective roofs on the overall energy savings of whole buildings
}

\author{
Hamed H. Saber ${ }^{1, *}$, Ali E. Hajiah ${ }^{2}$ and Wahid Maref ${ }^{3}$ \\ ${ }^{1}$ Jubail University College, Royal Commission of Jubail and Yanbu, Jubail Industrial City 31961, Kingdom of Saudi Arabia \\ ${ }^{2}$ Kuwait Institute for Scientific Research, Shuwaikh, Al-Jahidh Street, P.O. Box 24885, 13109 Safat, Kuwait \\ ${ }^{2}$ École de Technologie Supérieure (ETS), Montreal, University of Quebec, Montreal, Quebec H3C 1K3, Canada
}

\begin{abstract}
Many previous studies by the authors of this paper and others have shown that installing white/reflective/cool roofing systems resulted in energy savings. The amount of energy savings depended on the longwave thermal emissivity and the short-wave solar reflectivity of the rooftop surfaces. The question is "what is the percentage energy savings for the whole building as a result of using cool roofing systems instead of conventional/black roofing systems? To answer this question, three-dimensional energy simulations are conducted for typical Saudi buildings when they are subjected to the natural weathering conditions of the Eastern Province of Saudi Arabia. Several Window-to-Wall Ratios (WWRs) having different thermal resistances (R-values) and Solar Heat Gain Coefficients (SHGCs) are considered in the study. The windows are located in the different main solar orientations. To investigate the effect of the area ratio of the roof to the walls on the potential energy saving due to using cool roofs, one storey and twostorey are considered in this study. Results showed that using reflective materials with lower short-wave solar absorption coefficients in the roofing systems have resulted in a decrease in the yearly total energy loads of one-storey building and two-storey building.
\end{abstract}

\section{Introduction}

In regions with harsh climatic conditions, a substantial share of energy is used for heating the buildings in cold climates, and cooling the buildings in hot climates such that in Gulf Cooperation Council (GCC) countries. The design of building envelopes with the intent of achieving energy savings can necessarily help reduce building operating loads and thus the demand for energy over time. This research study mainly focuses on the performance of the whole building with reflective roofing systems and non-reflective (i.e. conventional/black) roofing system. When solar radiation hits the building envelope (i.e. roofs, walls, curtain walls, windows and skylight devices), a part of solar energy is reflected and the other part is absorbed. The absorbed part of solar energy results in an increase of the surface temperature of the building envelope. Typically, reflective/white/cool roofing systems use bright surfaces to reflect a significant portion of the incident short-wave solar radiation, which lowers the surface temperature compared to conventional roofing systems. As such, white roofing systems help reduce not only the urban heat island effect but also the cooling loads during the summertime.

To reduce the demand for electricity, it is important to design building envelopes in the GCC countries with the intent of achieving energy savings to help reduce building operating loads and thus the demand for energy over time. This study will focus on the energy performance of the whole building envelope that includes reflective and non-reflective roofing systems, wall systems and windows with different cardinal orientation and Window-to-Wall Ratio (WWR).

Many investigators [1-2, 4-15] have shown that green and reflective roofs can save energy, mitigate urban heat islands, slow global warming by decreasing greenhouse gas emissions, and reduce local air pollution while increasing thermal comfort. The effects of globally installing white roofs were assessed using an urban canyon model coupled to a global climate model [10].

Roofing systems with potential energy savings and low risk of moisture-related problems can help reduce the energy requirements for operating buildings, thereby reducing operating costs and contributing to the fight against global warming [16-18]. Ennis and Kehrer [19] investigated the effect of roof membrane colour on moisture accumulation in low-slope commercial roof systems. Their results showed that the amount of accumulated moisture for white roofs in winter was more than twice the amount for black roofs due to less solar energy gain needed for the dry-out process [19]. Bludau et al. [20] conducted hygrothermal simulations to investigate moisture build-up in white and black roofs under different climatic conditions. That study showed that black roofs always run with lower moisture compared to white roofs. Saber et al. [21-22] conducted

$\overline{{ }^{*} \text { Corresponding author: saberh@ucj.edu.sa }}$ 
hygrothermal simulations to investigate the moisture accumulation over time as well as energy use of white and black roofing systems when these roofs were subjected to different outdoor climates of North America. Results showed that black roofs always perform with lower moisture than white roofs. For the outdoor climates of St John's and Saskatoon, the black roofs have no risk of moisture damage. In these locations, the simulations suggest that the white roofs could lead to longer-term moisture-related problems.

Regarding to the energy performance of residential buildings, Al-ajmi and Hanby [23] conducted a parametric study to assess the energy consumption where only traditional sensible construction materials were considered. That study proposed several features that could be adopted to achieve more energy efficient buildings, including: (a) reducing the uncontrolled air infiltration rates, (b) control the sizes of windows and their orientations and placements in the facades, and (c) the use of certain treatments to the glazing to reduce the solar heat gain coefficients.

\section{Objectives}

The technology of solar reflective materials is currently being used in many countries across the globe. The ultimate goal of this study is to investigate the applicability of using this technology to enhance the energy performance of Saudi buildings.

As provided in a number of previous studies [2429], using reflective roofing systems of different insulation thicknesses with low short-wave solar absorption coefficients have resulted in significant reductions in the yearly energy load relative to conventional/black roofing systems with the same insulation thickness when these systems were subjected to environmental conditions of the coastal area of GCC countries. However, to investigate the impact of these reductions in the energy loads on the energy requirements for the whole building, it is important to conduct a follow-up study to assess the overall energy performance of the whole building instead of the roofing system only. As such, the main objective of this study is to determine the reductions in the energy loads of whole building with white roofing systems relative to the whole building with conventional roofing systems. This is because the overall energy performance of the whole building depends on a number of factors, namely:

1. Details of all components of the building envelope, namely (a) roofing systems, (b) wall systems, and (c) fenestration systems (doors, windows, skylight devices),

2. Cardinal orientations of the wall systems,

3. Cardinal orientations of the windows,

4. Window-to-wall ratios,

5. Number of storeys in the building,

6. Type of the building (attached or detached), and

7. Environmental conditions in which the building is subjected to.

\section{Research approach and methodology}

Three-dimensional numerical simulations are conducted to investigate the amount of energy savings in whole buildings as results of using reflective roofing systems instead of conventional roofing systems to answer the following two questions:

(a) What would be the amount of the reductions in the total energy loads for whole buildings as results of using reflective roofing systems with different short-wave solar absorption coefficients? and

(b) Are the reductions in the energy loads for the whole buildings significant enough that makes it worth specifying materials with low shortwave solar absorption coefficients?

To answer the two questions above, numerical simulations are conducted for reflective and conventional roofing systems shown in Figure 1 for the cases of single-zone building (Figure 3 ) and two-zone building (Figure 4).

\subsection{Indoor conditions}

The indoor conditions that are used for different roofing systems is based on ASHRAE recommendations for conditioned space, where the air temperature and relative humidity are $21^{\circ} \mathrm{C}$ and $30 \%$ Relative Humidity $(\mathrm{RH})$ in winter, and $24^{\circ} \mathrm{C}$ and $50 \% \mathrm{RH}$ in summer [30].

\subsection{Outdoor conditions}

All roofing systems are subjected to the weather conditions of the coastal area of GCC countries (Saudi Eastern Province).

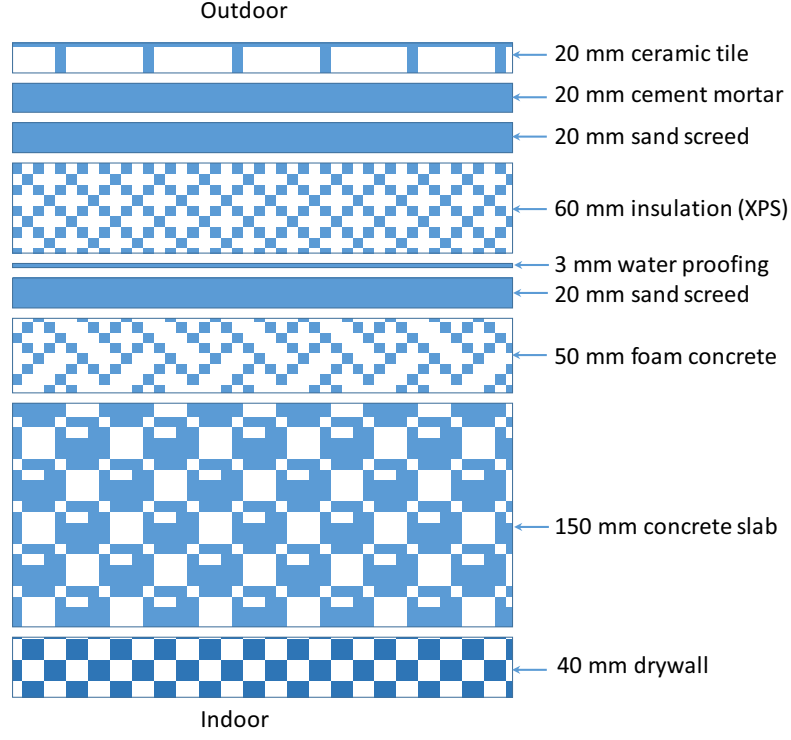

Figure 1. Schematics of roofing systems

\subsection{Material properties}

The hygrothermal properties of all materials of different roofing systems are obtained from the references [31, 32]. 


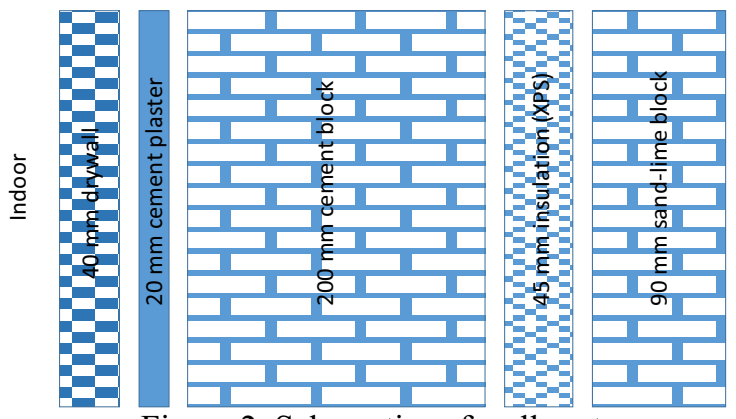

Figure 2. Schematics of wall system

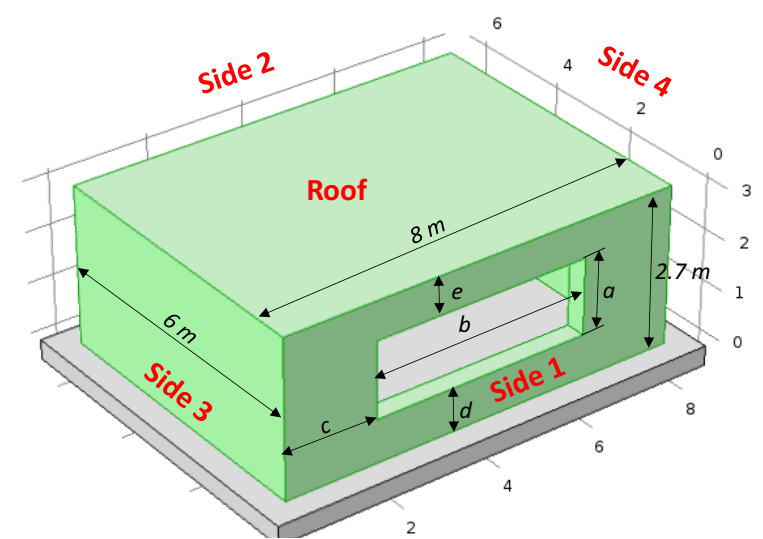

Figure 3. Schematic and dimensions of air-conditioned single-zone building

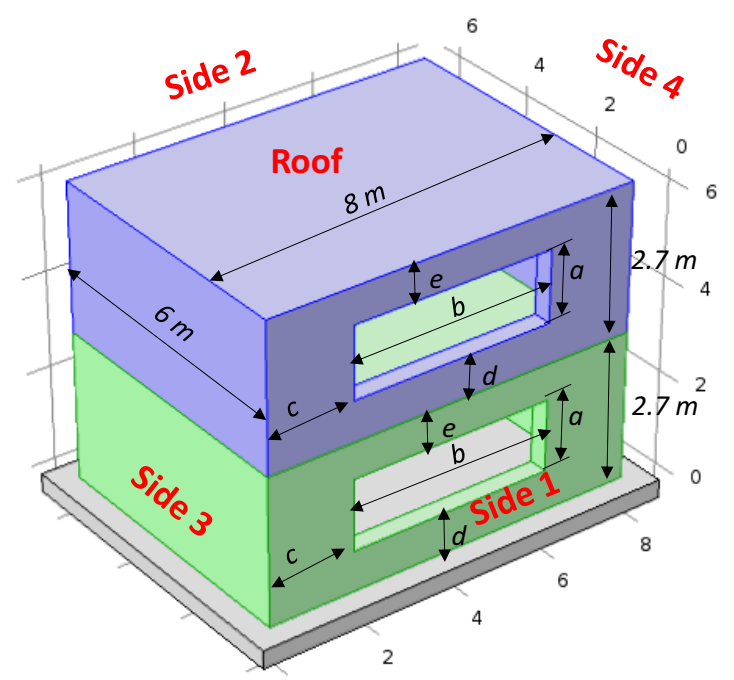

Figure 4. Schematic and dimensions of air-conditioned two-zone building

\subsection{Design variables}

Seven (7) Window-to-Wall Ratio (WWRs) of the main solar oriented window facades are considered in the study. Two cases were considered in this study, namely (a) single-zone buildings (Figure 3), and (b) twozone buildings (Figure 4).

In each case, 28 fully air-conditioned airspace as per ASHRAE recommendations for conditioned space [30] with seven WWRs facing the four cardinal directions were considered. The interior air volume remains as per ASHRAE 140 standard [33] where the interior dimensions of $8 \mathrm{~m} \times 6 \mathrm{~m} \times 2.7 \mathrm{~m}=129.6 \mathrm{~m}^{3}$. To reflect current, relatively dense, deep floor plan residential construction practices in GCC countries in which most spaces only have windows with one orientation, the windows with different WWRs were concentrated on one side for both cases of single-zone buildings and twozone buildings. The total floor area of the room is $48 \mathrm{~m}^{2}$ with a slab-on-grade foundation. All vertical surfaces are considered as external walls with no obstruction by neighboring buildings.

In accordance with the requirements in reference [3], Table 1 shows the specific glazing types for different WWR values. To prevent the boost of cooling energy demand when increasing the area of the fenestration systems, Table 1 shows that the higher the value of the WWR, the more selective the requirements of the glazing type, with lower U-factor and Solar Heat Gain Coefficient (SHGC) values. The different WWRs are obtained by changing the fenestration area as shown in Figure 3 for single-zone buildings and Figure 4 for twozone buildings. When the widows are located in the cardinal direction of side 1 or side 2 (see Figure 3 and Figure 4), the dimensions of these windows for different WWRs are provided in Table 2. Whereas, when the widows are located in the cardinal direction of side 3 or side 4 shown in Figure 3 and Figure 4, the dimensions of these windows for different WWRs are provided in Table 3.

According to Al-ajmi and Hanby [23], the traditional roofing system is almost universal in GCC countries and the exterior walls are mainly built of two types: Autoclaved Aerated Concrete (AAC) walls and concrete block walls called "classical walls". The latter exterior wall is cheaper, widely available, locally produced and structurally stronger than AAC. However, the AAC has the advantage of acting as thermal insulation, but there are few factories producing these blocks in GCC countries. In this study, the classical walls are considered in the numerical simulations. Figure 1 shows a cross-section and dimensions of the reference and test roofing systems. Whereas Figure 2 shows a cross-section and dimensions of the reference and test wall systems. Figure 1 and Figure 2, respectively, show the wall and roofing systems.

Table 1. Different types of glazing for different windowto Wall-Ratios (WWRs) in accordance with the reference [3]

\begin{tabular}{|c|c|c|c|c|}
\hline $\begin{array}{c}\text { Window } \\
\text { Case }\end{array}$ & WWR & Glazing type required & $\begin{array}{c}\text { U-factor } \\
\mathrm{W} /\left(\mathrm{m}^{2} \mathrm{~K}\right)\end{array}$ & SHGC \\
\hline W1 & $10 \%$ & $6 \mathrm{~mm}$ double-tinted & 3.42 & 0.36 \\
\hline W2 & $20 \%$ & $6 \mathrm{~mm}$ double-reflective & 3.38 & 0.254 \\
\hline W3 & $30 \%$ & $6 \mathrm{~mm}$ double-reflective & 3.38 & 0.254 \\
\hline W4 & $40 \%$ & $6 \mathrm{~mm}$ double-reflective & 3.38 & 0.254 \\
\hline W5 & $50 \%$ & $\begin{array}{c}6 \mathrm{~mm} \text { double-spectrally } \\
\text { selective }\end{array}$ & 1.71 & 0.23 \\
\hline W6 & $60 \%$ & $\begin{array}{c}6 \mathrm{~mm} \text { double-spectrally } \\
\text { selective }\end{array}$ & 1.71 & 0.23 \\
\hline W7 & $70 \%$ & $\begin{array}{c}6 \mathrm{~mm} \text { double-spectrally } \\
\text { selective }\end{array}$ & 1.71 & 0.23 \\
\hline
\end{tabular}


Table 2. Dimensions of the windows located in Side 1 or Side 2 (see Figure 3 and Figure 4)

\begin{tabular}{|c|c|c|c|c|c|c|c|c|}
\hline $\begin{array}{c}\text { Window } \\
\text { Case }\end{array}$ & WWR & $\begin{array}{c}\mathrm{a} \\
(\mathrm{m})\end{array}$ & $\begin{array}{c}\mathrm{b} \\
(\mathrm{m})\end{array}$ & $\begin{array}{c}\mathrm{c} \\
(\mathrm{m})\end{array}$ & $\begin{array}{c}\mathrm{d} \\
(\mathrm{m})\end{array}$ & $\begin{array}{c}\mathrm{e} \\
(\mathrm{m})\end{array}$ & $\begin{array}{c}\mathrm{A}_{\mathrm{wa}} \\
\left(\mathrm{m}^{2}\right)\end{array}$ & $\begin{array}{c}\mathrm{A}_{\mathrm{wi}} \\
\left(\mathrm{m}^{2}\right)\end{array}$ \\
\hline $\mathrm{W} 1$ & $10 \%$ & 1.00 & 2.16 & 2.92 & 1.35 & 0.35 & 21.60 & 2.16 \\
\hline $\mathrm{W} 2$ & $20 \%$ & 1.00 & 4.32 & 1.84 & 1.35 & 0.35 & 21.60 & 4.32 \\
\hline $\mathrm{W} 3$ & $30 \%$ & 1.50 & 4.32 & 1.84 & 0.85 & 0.35 & 21.60 & 6.48 \\
\hline $\mathrm{W} 4$ & $40 \%$ & 1.50 & 5.76 & 1.12 & 0.85 & 0.35 & 21.60 & 8.64 \\
\hline $\mathrm{W} 5$ & $50 \%$ & 2.00 & 5.40 & 1.30 & 0.35 & 0.35 & 21.60 & 10.80 \\
\hline $\mathrm{W} 6$ & $60 \%$ & 2.00 & 6.48 & 0.76 & 0.35 & 0.35 & 21.60 & 12.96 \\
\hline $\mathrm{W} 7$ & $70 \%$ & 2.00 & 7.56 & 0.22 & 0.35 & 0.35 & 21.60 & 15.12 \\
\hline
\end{tabular}

Table 3. Dimensions of the windows located in Side 3 or Side 4 (see Figure 3 and Figure 4)

\begin{tabular}{|c|c|c|c|c|c|c|c|c|}
\hline $\begin{array}{c}\text { Window } \\
\text { Case }\end{array}$ & WWR & $\begin{array}{c}\mathrm{a} \\
(\mathrm{m})\end{array}$ & $\begin{array}{c}\mathrm{b} \\
(\mathrm{m})\end{array}$ & $\begin{array}{c}\mathrm{c} \\
(\mathrm{m})\end{array}$ & $\begin{array}{c}\mathrm{d} \\
(\mathrm{m})\end{array}$ & $\begin{array}{c}\mathrm{e} \\
(\mathrm{m})\end{array}$ & $\begin{array}{c}\mathrm{A}_{\mathrm{wa}} \\
\left(\mathrm{m}^{2}\right)\end{array}$ & $\begin{array}{c}\mathrm{A}_{\mathrm{wi}} \\
\left(\mathrm{m}^{2}\right)\end{array}$ \\
\hline $\mathrm{W} 1$ & $10 \%$ & 1.00 & 1.62 & 2.19 & 1.35 & 0.35 & 16.20 & 1.62 \\
\hline $\mathrm{W} 2$ & $20 \%$ & 1.00 & 3.24 & 1.38 & 1.35 & 0.35 & 16.20 & 3.24 \\
\hline $\mathrm{W} 3$ & $30 \%$ & 1.50 & 3.24 & 1.38 & 0.85 & 0.35 & 16.20 & 4.86 \\
\hline $\mathrm{W} 4$ & $40 \%$ & 1.50 & 4.32 & 0.84 & 0.85 & 0.35 & 16.20 & 6.48 \\
\hline $\mathrm{W} 5$ & $50 \%$ & 2.00 & 4.05 & 0.98 & 0.35 & 0.35 & 16.20 & 8.10 \\
\hline $\mathrm{W} 6$ & $60 \%$ & 2.00 & 4.86 & 0.57 & 0.35 & 0.35 & 16.20 & 9.72 \\
\hline W7 & $70 \%$ & 2.00 & 5.67 & 0.17 & 0.35 & 0.35 & 16.20 & 11.34 \\
\hline
\end{tabular}

\section{Results and discussions}

Numerical simulations were conducted for different wall system shown in Figure 2 when this system is subjected to weather conditions of Saudi Eastern Province and facing the four cardinal directions (see side 1 through side 4 in Figure 3 and Figure 4 for the cases of single-zone buildings and two-zone buildings, respectively). The temperature, heat flux and moisture distributions in the wall system were obtained by solving the energy equation and moisture equation in different layers. The predicted heat fluxes on the indoor surface of these wall systems were used to determine the contributions to the monthly heating and cooling energy loads.

\subsection{Effect of wall orientation on the energy performance}

Since no reflective material is installed on the outdoor surfaces of the wall systems, the short-wave solar absorption coefficient $\left(\alpha_{s}\right)$ is 0.88 [20-22]. For the cases of single-zone buildings and two-zone buildings, numerical simulations were conducted to predict the contributions to the cooling and heating energy loads of wall system when this wall was located in the four cardinal directions (side 1 through side 4, see Figure 3 and Figure 4) and subjected to the weather conditions of Saudi Eastern Province.

Figure 5a (wall in side 1), Figure 5b (wall in side 2), Figure 5c (wall in side 3) and Figure 5d (wall in side 4) show the contributions to the monthly cooling energy load (+ve values) and the monthly heating load (-ve values). The corresponding results for the case of twozone buildings are provided in Figure 6a (wall in side 1), Figure 6b (wall in side 2) Figure 6c (wall in side 3), and
Figure 6d (wall in side 4). For a given cardinal direction, these figures show the contributions to the monthly cooling loads are significantly higher than the monthly heating loads. The highest contributions to the cooling loads occurred in the month of August for walls located in side 1 , side 2 and side 3 , and in month of July for walls located in side 4 . Whereas the highest contributions to the heating loads occurred in the month of January for walls located in the four cardinal directions.

In cold climates, the sources of heating loads in residential buildings are usually obtained using heaters or furnaces that use fossil fuel; whereas the sources of the cooling loads are obtained using coolers or $\mathrm{A} / \mathrm{C}$ systems that use electrical energy. Because of the difference in prices per thermal unit between the fossil fuel and electrical energy, the cooling energy load and heating energy load should be provided separately [2022]. However, in hot climates such as that in GCC countries, the source of the heating loads and cooling loads in residential buildings are obtained using heaters, coolers or $\mathrm{A} / \mathrm{C}$ systems that use electrical energy. Consequently, the total energy loads in hot climates can be obtained as the sum of the cooling loads and the heating loads as provided in Figure 5a through Figure 5d (the case of single-zone buildings) and Figure 6a through Figure $6 \mathrm{~d}$ (the case of two-zone buildings).

The results show that the months of the highest contributions to the total energy loads of different wall systems occurred in July and August. However, the months of lowest contributions to the total energy loads depended on the cardinal direction of the wall systems. For example, the lowest contributions to the heating loads for the wall system located in side 1 occurred in November, whereas that for the wall systems located in side 4 occurred in March.

The wall system shown in Figure 2 for the cases of single-zone buildings and two-zone buildings are identical. This wall system is subjected to the weather conditions of Saudi Eastern Province. So, all values of different weather parameters (temperature, relative humidity, etc.) are the same for both cases of single-zone buildings and two-zone buildings except for the wind speed. This is because the wind speed increases with increasing the elevation measured from the ground resulting in higher convective heat transfer coefficient for the high elevation than that for low elevation. As such, the contributions to the cooling energy loads of different wall systems for the case of two-zone buildings of $5.4 \mathrm{~m}$ tall (Figure 4) were predicted from the numerical simulations to be lower than that for the case of single-zone buildings of $2.7 \mathrm{~m}$ tall (Figure 3). For example, the contributions to the total energy loads in the month of July for the wall located in side 1 for the case of two-zone buildings $\left(332.7 \mathrm{Wd} / \mathrm{m}^{2}\right.$, Figure $6 \mathrm{a}$ ) was $2 \%$ lower than that for the case of single-zone buildings (338.6 Wd/ $\mathrm{m}^{2}$, Figure $5 \mathrm{a}$ ). 


\subsection{Yearly energy loads of different zone buildings}

In accordance with the reference [3], different types of glazing for different window-to Wall-Ratios (WWR = $10 \%-70 \%$ ) as provided in Table 1 were considered in this study. Numerical simulations were conducted for single-zone buildings and two-zone buildings when the different windows (W1 through W7, see Table 1), were located in different cardinal orientations (side 1 through side 4). The dimensions of the windows located in side 1 and side 2 are given in Table 2. Whereas the dimensions of the windows located in side 3 and side 4 are given in Table 3. For single-zone buildings and twozone buildings, all simulation cases include SI-WJ where $\mathrm{I}=1,2,3$ and 4 , and $\mathrm{J}=1,2,3,4,5,6$ and 7 .
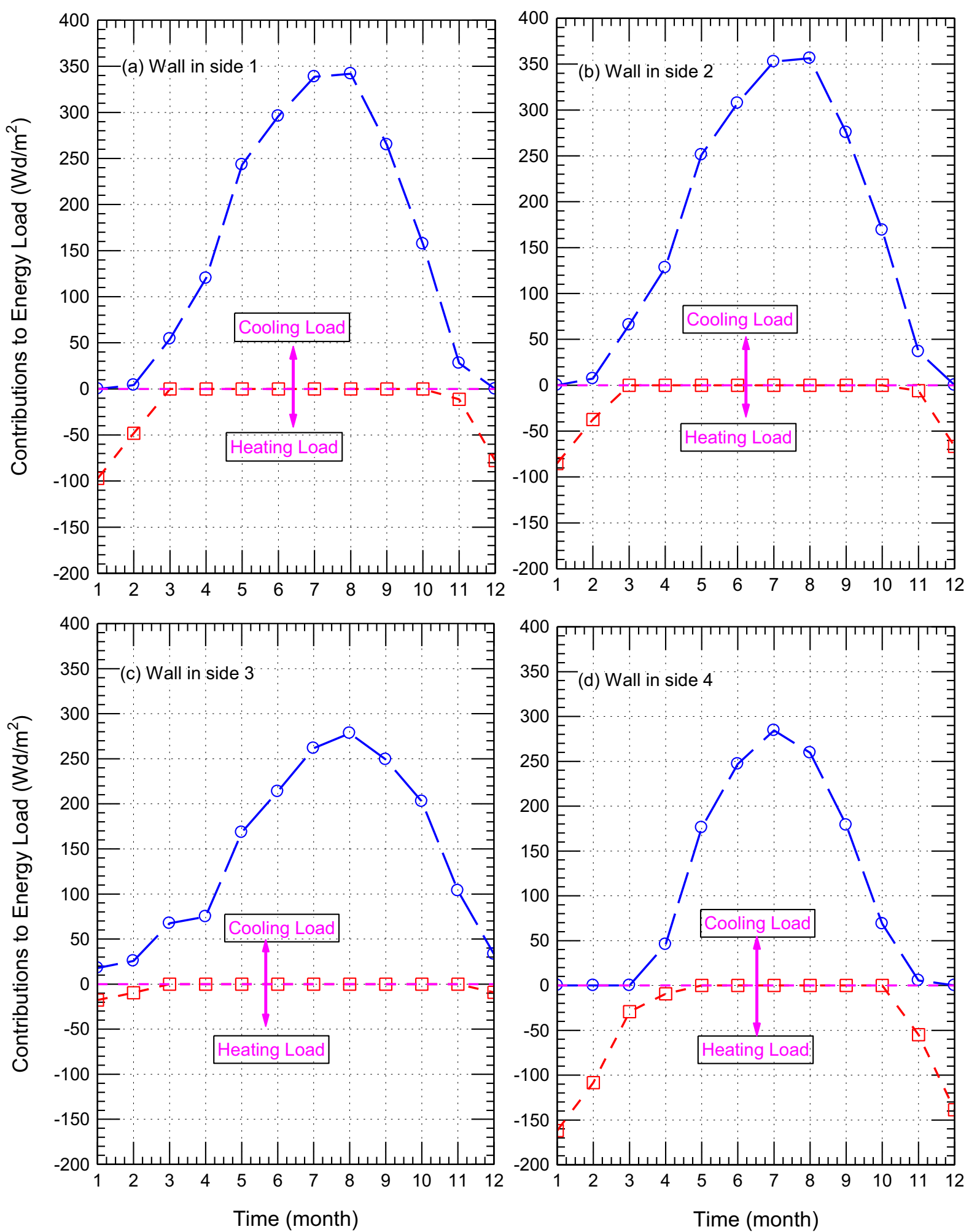

Figure 5. Contributions to the monthly heating and cooling energy loads of wall located in different sides for $\alpha_{s}=0.88$ (single-zone) 

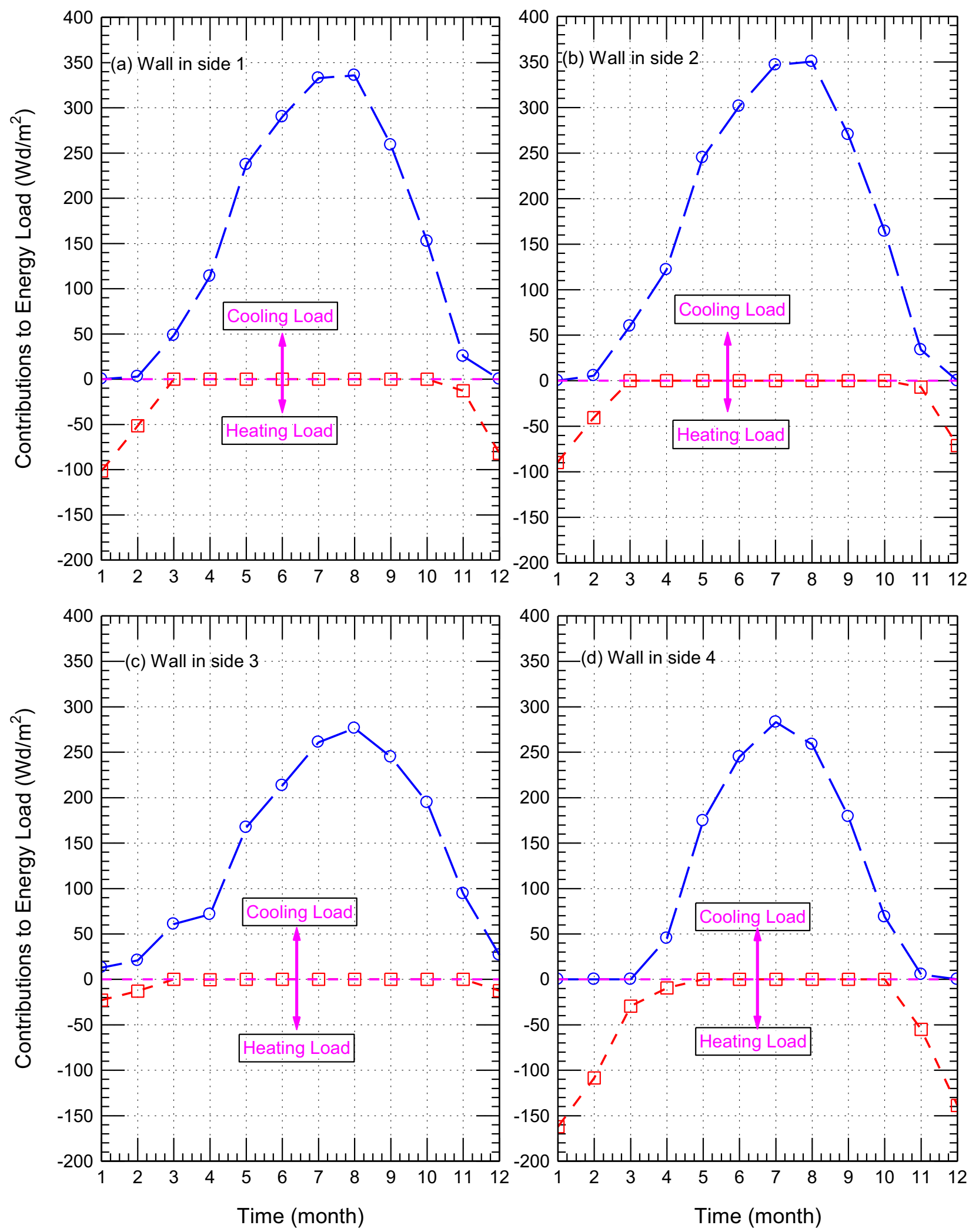

Figure 6. Contributions to the monthly heating and cooling energy loads of wall located in different sides for $\alpha_{s}=0.88$ (two-zone)

Note that SI-WJ refers to the simulation case of window WJ (i.e. W1 through W7, see Table 1, Table 2, and Table 3) when it is located in the side I (i.e. side 1 through side 4) and no windows in the other sides. For example, the simulation case "S2-W5" refers to the case of window W5 (see Table 1, Table 2, and Table 3) when it is located in side 2 (i.e. S2) and no windows in the other sides (i.e. side 1, side 3 and side 4).

For different combinations of windows located in the different cardinal orientations with different WWRs, the numerical simulations for single-zone buildings and twozone buildings were conducted for roofing systems having different reflective materials with different short- 
wave solar absorption coefficients, namely: $\alpha_{\mathrm{s}}=0.88$ (black/conventional roof), $\alpha_{\mathrm{s}}=0.6, \alpha_{\mathrm{s}}=0.4$, and $\alpha_{\mathrm{s}}=$ 0.2 . This paper provides only the results for single-zone buildings and two-zone buildings for the cases of conventional roofing systems $\left(\alpha_{\mathrm{s}}=0.88\right)$ and white roofing system having $\alpha_{\mathrm{s}}=0.2$.

For the cases of single-zone buildings with roofing systems having different values of the short-wave solar absorption coefficients $\left(\alpha_{s}\right)$, the obtained results of the yearly cooling energy loads and the yearly total loads are provided in Figure 7 through Figure 10 (for $\alpha_{\mathrm{s}}=0.88$ ) and Figure 11 through Figure 14 (for $\alpha_{\mathrm{s}}=0.2$ ). As well, the corresponding results for the case of two-zone buildings are provided in Figure 15 through Figure 18 (for $\alpha_{\mathrm{s}}=0.88$ ) and Figure 19 through Figure 22 (for $\alpha_{\mathrm{s}}=$ $0.2)$.

As shown in Figure 7 through Figure 14 for different single-zone buildings and Figure 15 through Figure 22 for different two-zone buildings, decreasing the shortwave solar absorption coefficient for the roofing systems has resulted in a decrease in the yearly cooling loads and the yearly total loads. Note that the differences between the yearly total loads in Figure $7 \mathrm{~b}$ through Figure 22b and the yearly cooling loads in Figure 7 a through Figure 22a represent the yearly heating loads of different types of single-zone buildings and two-zone buildings.

\subsection{Effect of window orientation on the yearly energy loads}

For the sizes and properties of different windows with different WWRs as provided in Table 1, Table 2 and Table 3 when these windows were located in the four cardinal directions, Figure 7 through Figure 14 for different single-zone buildings and Figure 15 through Figure 22 for different two-zone buildings show that the window case of $\mathrm{W} 1(\mathrm{WWR}=10 \%$, U-factor $=3.42$ $\mathrm{W} /\left(\mathrm{m}^{2} \mathrm{~K}\right)$ and $\left.\mathrm{SHGC}=0.36\right)$ has resulted in the lowest yearly cooling loads and yearly total loads. While the window case of W4 $(\mathrm{WWR}=40 \%$, U-factor $=3.38$ $\mathrm{W} /\left(\mathrm{m}^{2} \mathrm{~K}\right)$ and $\left.\mathrm{SHGC}=0.254\right)$ has resulted in the highest yearly cooling loads and yearly total loads. For example, for the window case W4 located in side 1 (i.e. S1-W4) in single-zone buildings having a roofing system with a short-wave solar absorption coefficient of 0.88 (i.e. black/conventional roof), the yearly cooling load was $5872.9 \mathrm{kWh}$ (Figure 7a), and the corresponding yearly total load was $6637.2 \mathrm{kWh}$ (Figure $7 \mathrm{~b}$ ). However, replacing the window case $\mathrm{W} 4$ located in side 1 by the window case W1 located in the same side (i.e. side 1) has resulted in lower yearly cooling load $(5308.9 \mathrm{kWh})$ by $10.6 \%$ and lower yearly total load $(5856.6 \mathrm{kWh})$ by $13.3 \%$.

For a given cardinal direction (side 1 through side 4) and a short-wave solar absorption coefficient for the roofing system $(0.88,0.6,0.4$ and 0.2$)$, the order of the window cases starting from that resulted in the lowest energy loads to that resulted in the highest energy loads are as following:
(1) $\mathrm{W} 1\left(\mathrm{WWR}=10 \%\right.$, U-factor $=3.42 \mathrm{~W} /\left(\mathrm{m}^{2} \mathrm{~K}\right)$ and $\mathrm{SHGC}=0.36)$

(2) $\mathrm{W} 2\left(\mathrm{WWR}=20 \%\right.$, U-factor $=3.38 \mathrm{~W} /\left(\mathrm{m}^{2} \mathrm{~K}\right)$ and $\mathrm{SHGC}=0.254)$,

(3) $\mathrm{W} 5\left(\mathrm{WWR}=50 \%\right.$, U-factor $=1.71 \mathrm{~W} /\left(\mathrm{m}^{2} \mathrm{~K}\right)$ and $\mathrm{SHGC}=0.23)$

(4) $\mathrm{W} 6\left(\mathrm{WWR}=60 \%\right.$, U-factor $=1.71 \mathrm{~W} /\left(\mathrm{m}^{2} \mathrm{~K}\right)$ and $\mathrm{SHGC}=0.23)$,

(5) $\mathrm{W} 3\left(\mathrm{WWR}=30 \%\right.$, U-factor $=3.38 \mathrm{~W} /\left(\mathrm{m}^{2} \mathrm{~K}\right)$ and $\mathrm{SHGC}=0.254)$,

(6) $\mathrm{W} 7\left(\mathrm{WWR}=70 \%\right.$, U-factor $=1.71 \mathrm{~W} /\left(\mathrm{m}^{2} \mathrm{~K}\right)$ and SHGC $=0.23$ ), and lastly

(7) $\mathrm{W} 4\left(\mathrm{WWR}=40 \%\right.$, U-factor $=3.38 \mathrm{~W} /\left(\mathrm{m}^{2} \mathrm{~K}\right)$ and $\mathrm{SHGC}=0.254$ ).

As shown in Figure 7 through Figure 14 for different single-zone buildings and Figure 15 through Figure 22 for different two-zone buildings, for a given window case (W1 through W7, see Table 1) and a short-wave solar absorption coefficient for the roofing system, locating the window in the cardinal direction of side 4 has resulted in the lowest yearly cooling loads and yearly total loads. Whereas, locating the window in the cardinal direction of side 2 has resulted in the highest yearly cooling loads and yearly total loads. For example, for the window case W4 located in side 2 (i.e. S2-W4) in single-zone buildings having a roofing system with a short-wave solar absorption coefficient of 0.88 (i.e. black/conventional roof), the yearly cooling load was $5871.6 \mathrm{kWh}$ (Figure 8a), and the corresponding yearly total load was $6636.2 \mathrm{kWh}$ (Figure $8 \mathrm{~b}$ ). Just only relocating the same window in side 4 (i.e. S4-W4) instead of side 2 has resulted in lower yearly cooling load ( $5632.4 \mathrm{kWh}$, Figure $10 \mathrm{a}$ ) by $4.3 \%$ and lower yearly total load (6328.6 kWh, Figure 10b) by $4.9 \%$.

\subsection{Effect of short-wave solar absorption coefficient of the roofing systems on the yearly energy loads}

For a given cardinal orientation of the window in both single-zone buildings and two-zone buildings, decreasing the short-wave solar absorption coefficient of the roofing system has resulted in decreasing the energy loads. As indicated earlier, for a given cardinal direction of the window, the window cases W1 and W4, respectively, have resulted the lowest and highest energy loads compared to other window cases for different single-zone buildings and two-zone buildings. For example, decreasing the short-wave solar absorption coefficient from 0.88 to 0.2 for the window case S1-W1 has resulted in decreasing the yearly total energy load by $13.0 \%$ (from $5856.6 \mathrm{kWh}$ to $5184.6 \mathrm{kWh}$, Figure $7 \mathrm{~b}$ ) and $6.8 \%$ (from $9383.6 \mathrm{kWh}$ to $8786.4 \mathrm{kWh}$, Figure $15 \mathrm{~b}$ ) for the cases of single-zone building and two-zone building, respectively. For the window case S1-W4, decreasing the short-wave solar absorption coefficient from 0.88 to 0.2 has resulted in decreasing the yearly total energy load by $10.2 \%$ (from $6637.2 \mathrm{kWh}$ to $6024.6 \mathrm{kWh}$, Figure $7 \mathrm{~b}$ ) and $5.0 \%$ (from $11026.3 \mathrm{kWh}$ to $10504.4 \mathrm{kWh}$, Figure $15 \mathrm{~b}$ ) for the cases of single-zone building and two-zone building, respectively. 


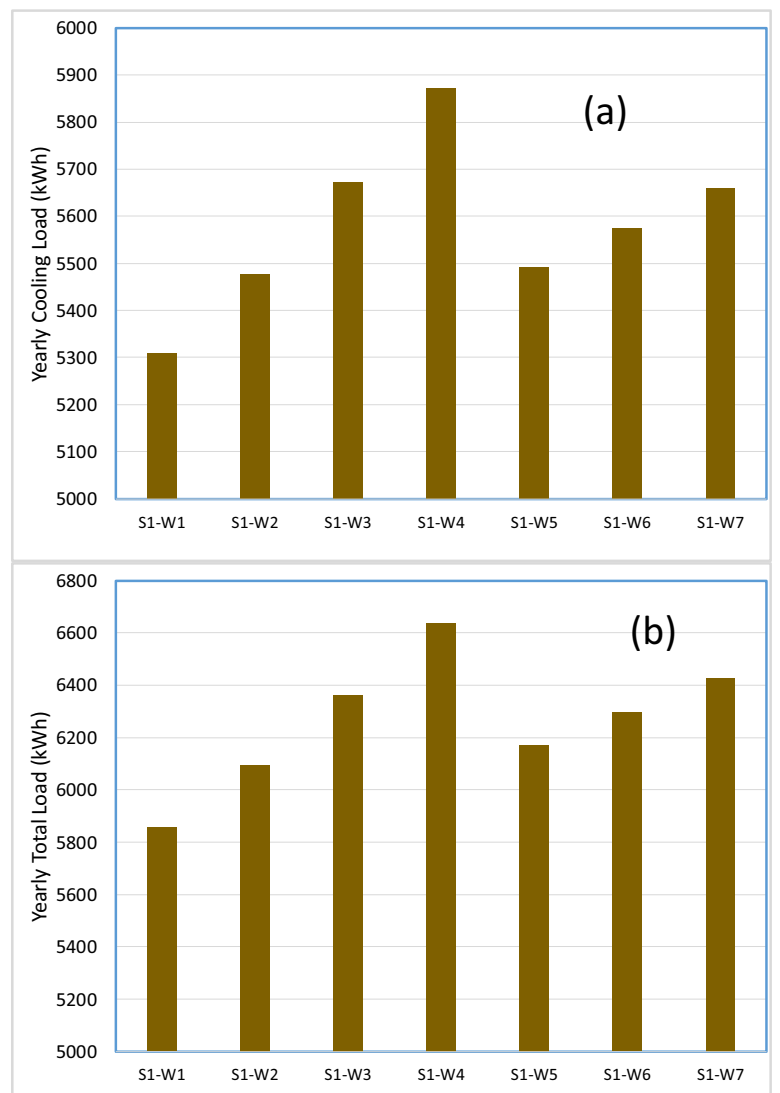

Figure 7. Yearly cooling and total loads when windows in Side 1 for the case of single-zone with roof having $\alpha_{\mathrm{s}}$ $=0.88$
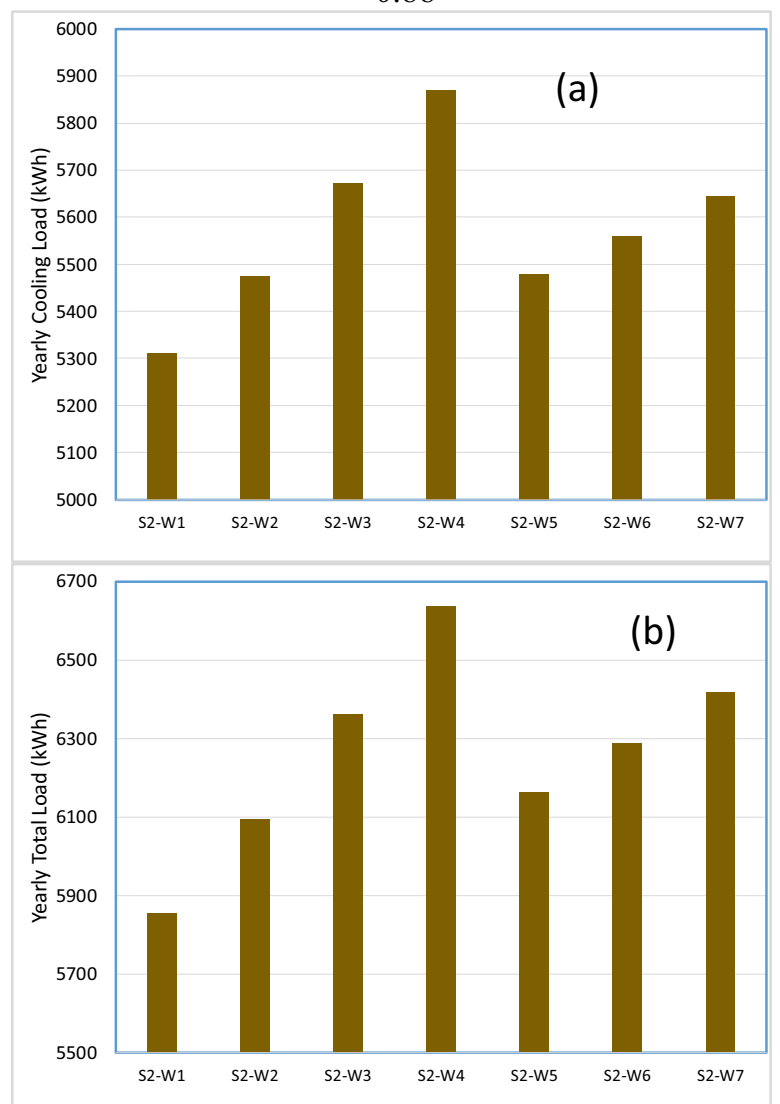

Figure 8. Yearly cooling and total loads when windows in Side 2 for the case of single-zone with roof having $\alpha_{\mathrm{s}}$ $=0.88$

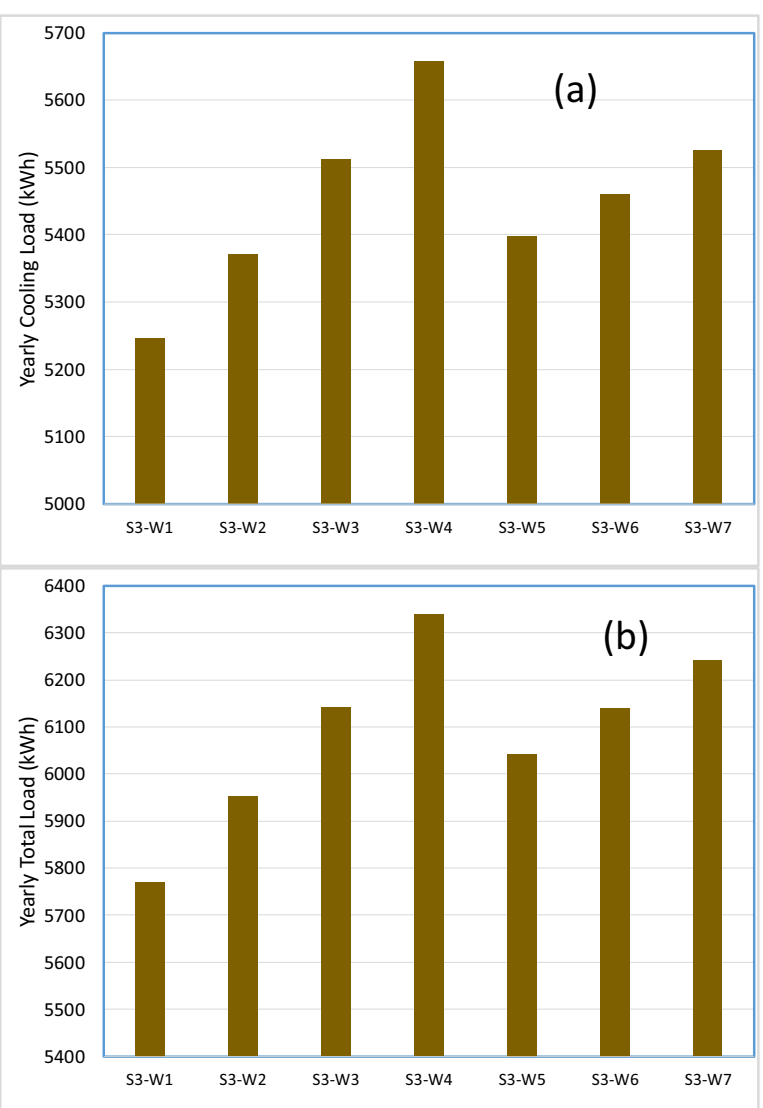

Figure 9. Yearly cooling and total loads when windows in Side 3 for the case of single-zone with roof having $\alpha_{s}$ $=0.88$
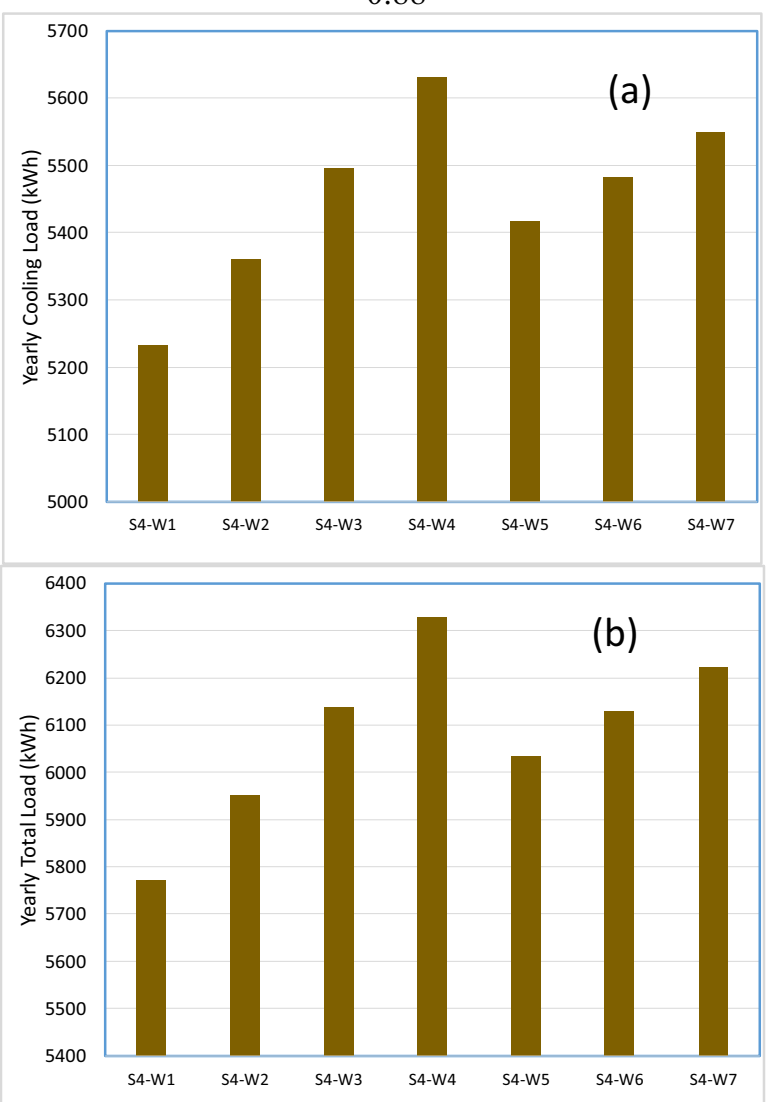

Figure 10. Yearly cooling and total loads when windows in Side 4 for the case of single-zone with roof having $\alpha_{\mathrm{s}}$ $=0.88$ 


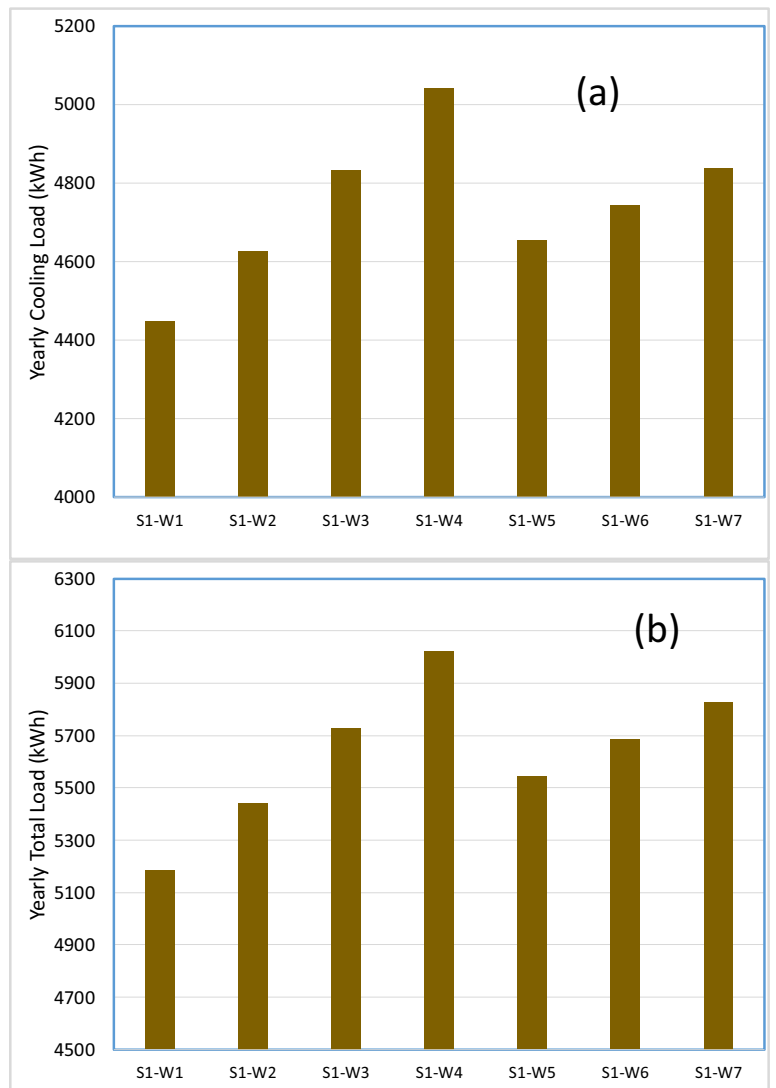

Figure 11. Yearly cooling and total loads when windows in Side 1 for the case of single-zone with roof having $\alpha_{s}$ $=0.2$
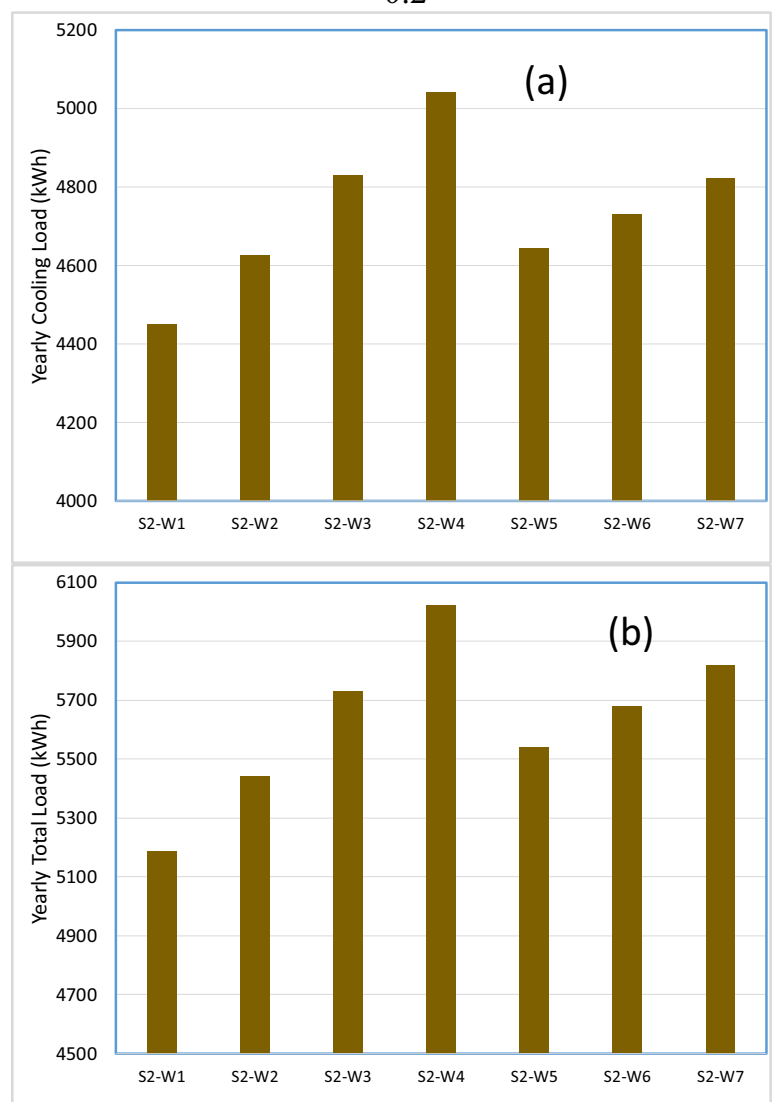

Figure 12. Yearly cooling and total loads when windows in Side 2 for the case of single-zone with roof having $\alpha_{\mathrm{s}}$ $=0.2$
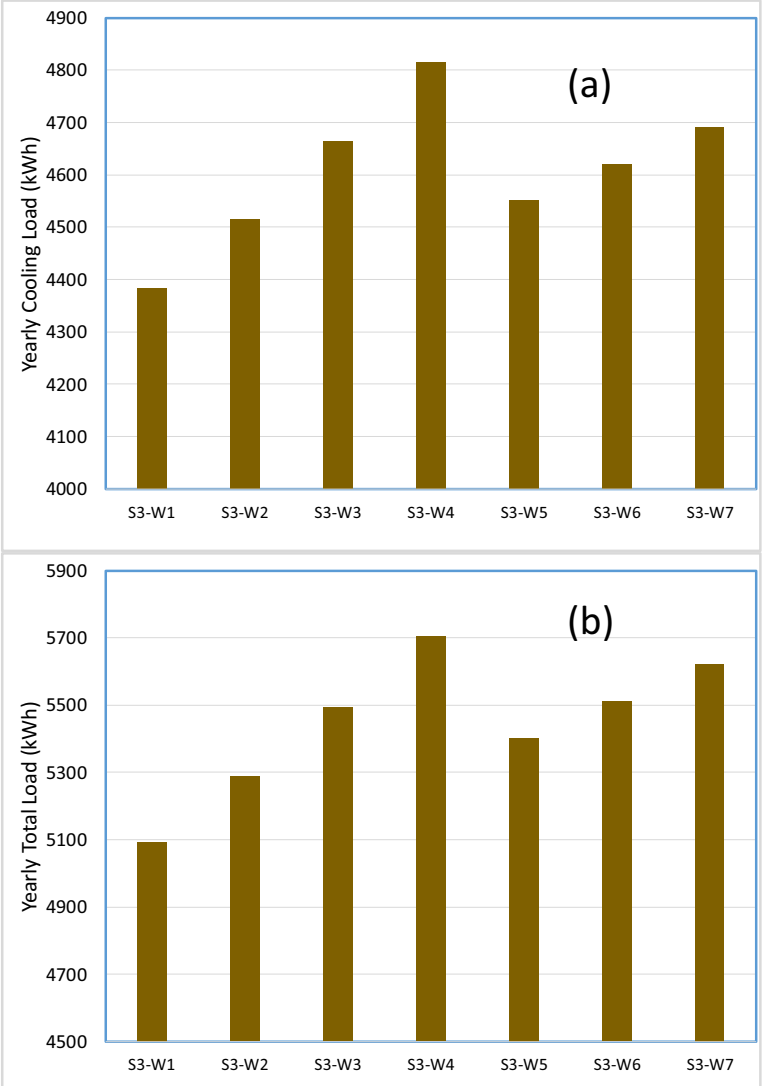

Figure 13. Yearly cooling and total loads when windows in Side 3 for the case of single-zone with roof having $\alpha_{s}$ $=0.2$
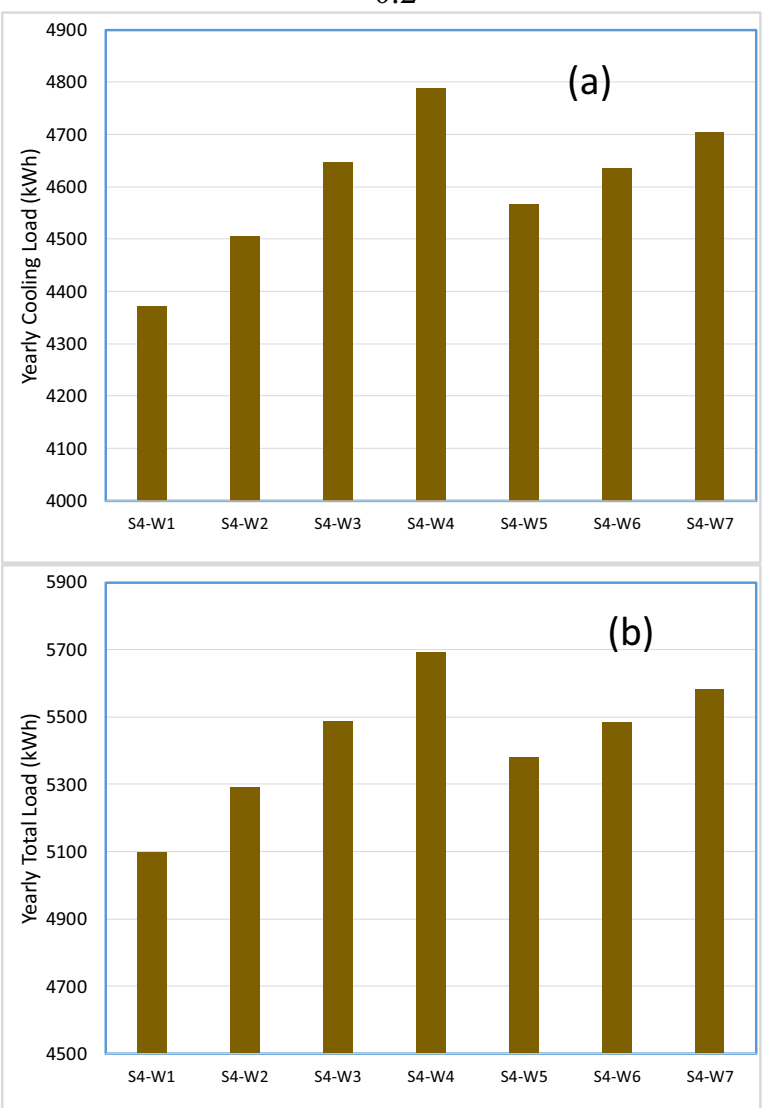

Figure 14. Yearly cooling and total loads when windows in Side 4 for the case of single-zone with roof having $\alpha_{s}$ $=0.2$ 


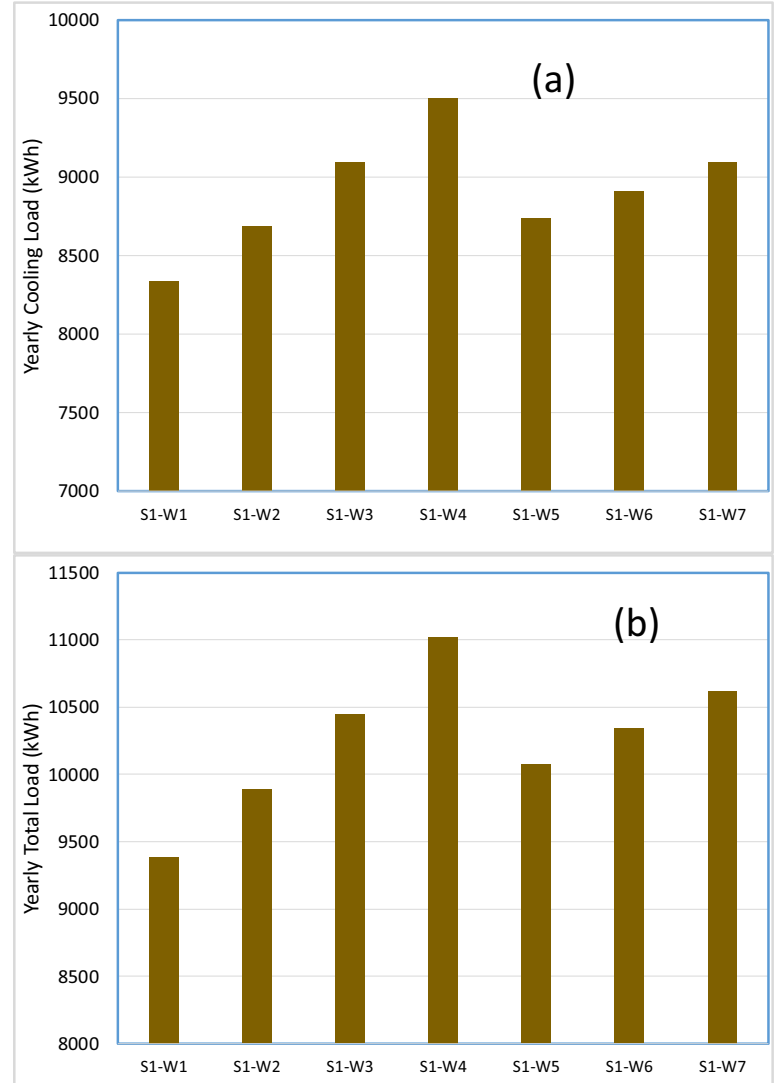

Figure 15 . Yearly cooling and total loads when windows in Side 1 for the case of two-zone with roof having $\alpha_{\mathrm{s}}=$ 0.88

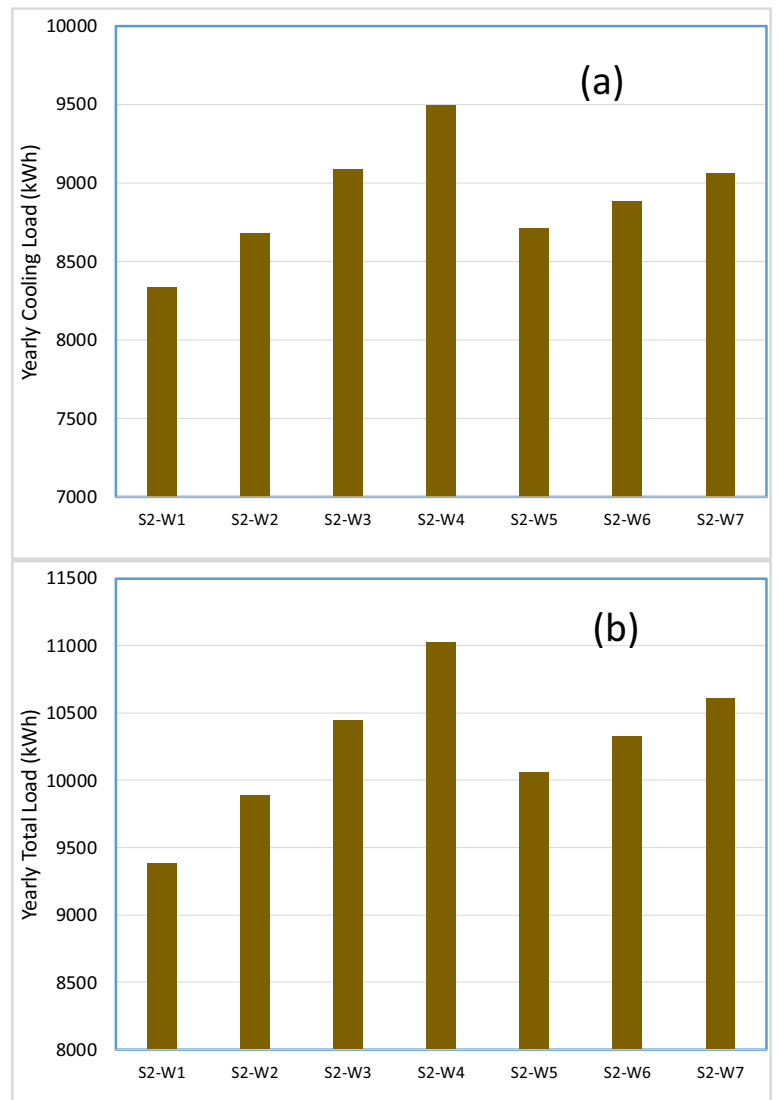

Figure 16. Yearly cooling and total loads when windows in Side 2 for the case of two-zone with roof having $\alpha_{\mathrm{s}}=$ 0.88

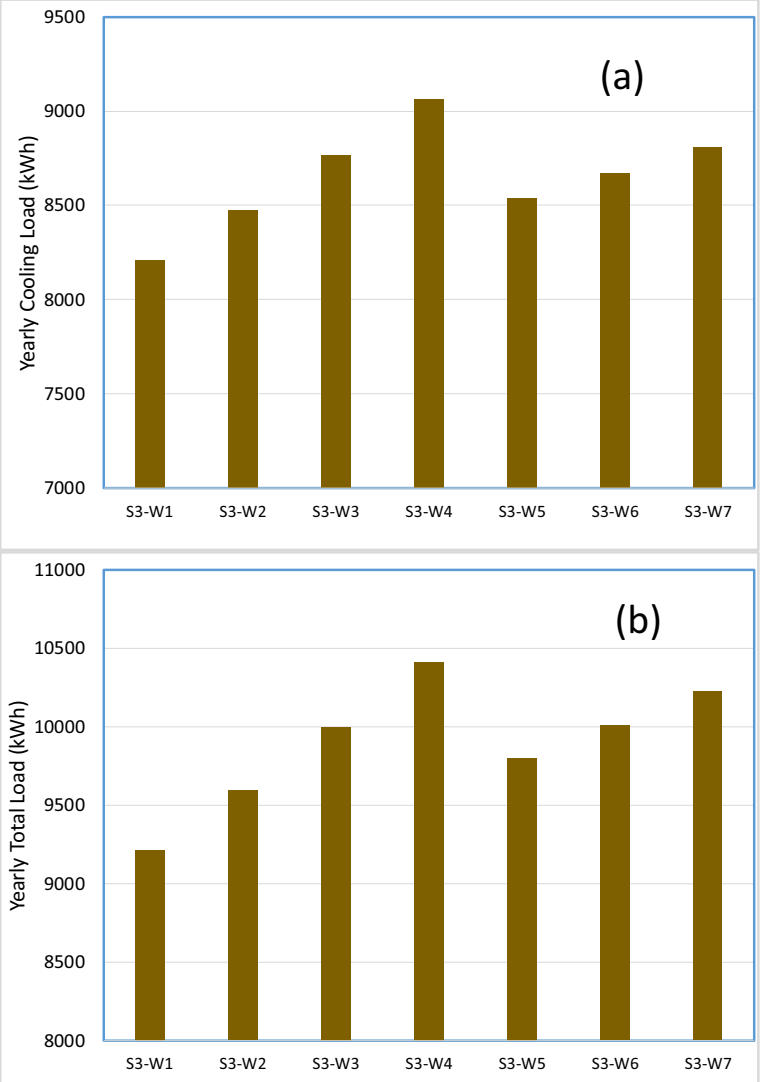

Figure 17. Yearly cooling and total loads when windows in Side 3 for the case of two-zone with roof having $\alpha_{s}=$ 0.88

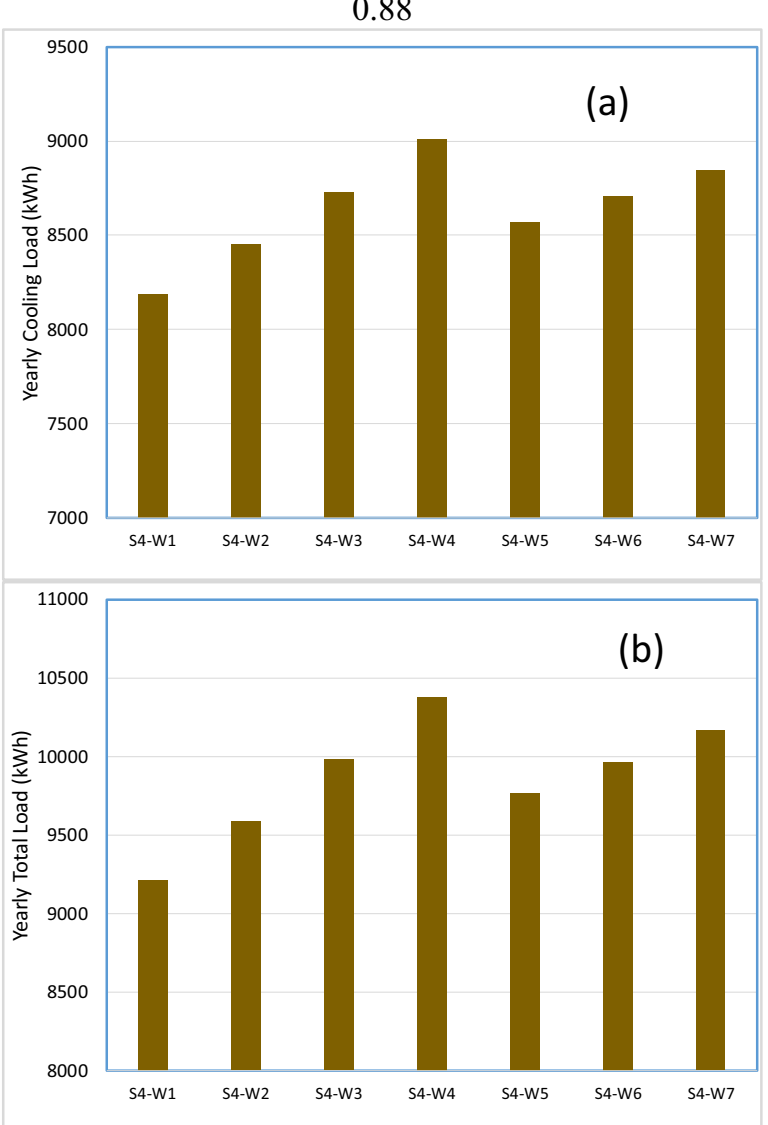

Figure 18. Yearly cooling and total loads when windows in Side 4 for the case of two-zone with roof having $\alpha_{\mathrm{s}}=$ 0.88 


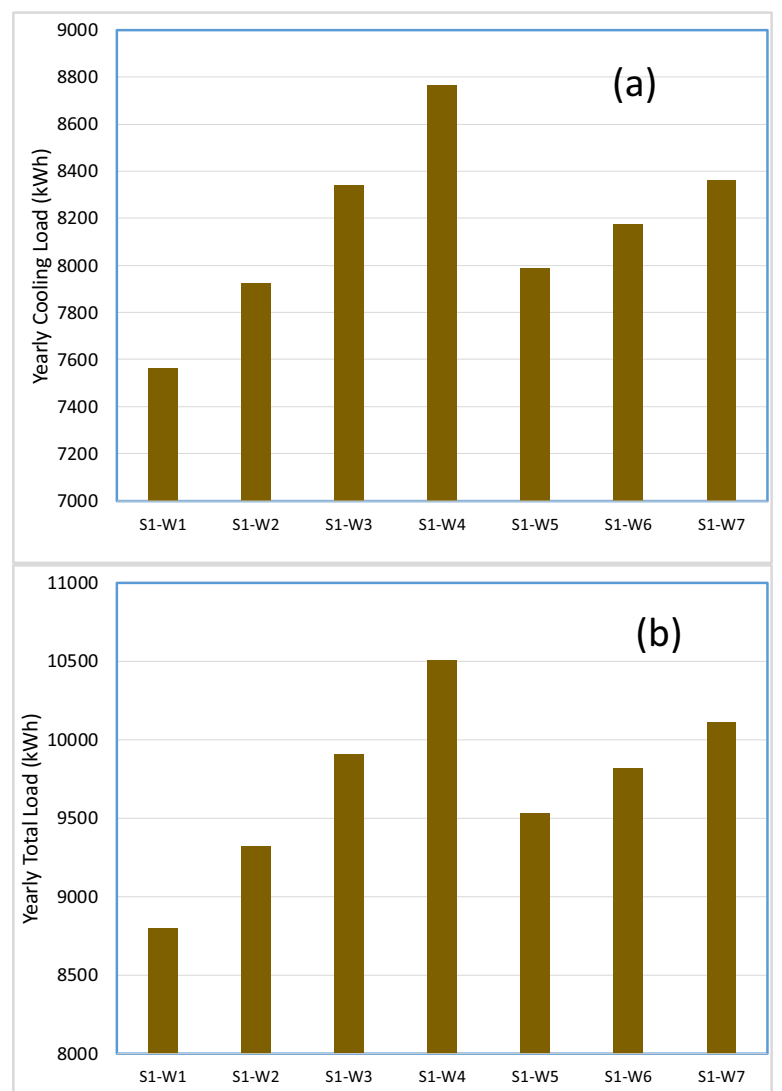

Figure 19. Yearly cooling and total loads when windows in Side 1 for the case of two-zone with roof having $\alpha_{\mathrm{s}}=$ 0.2
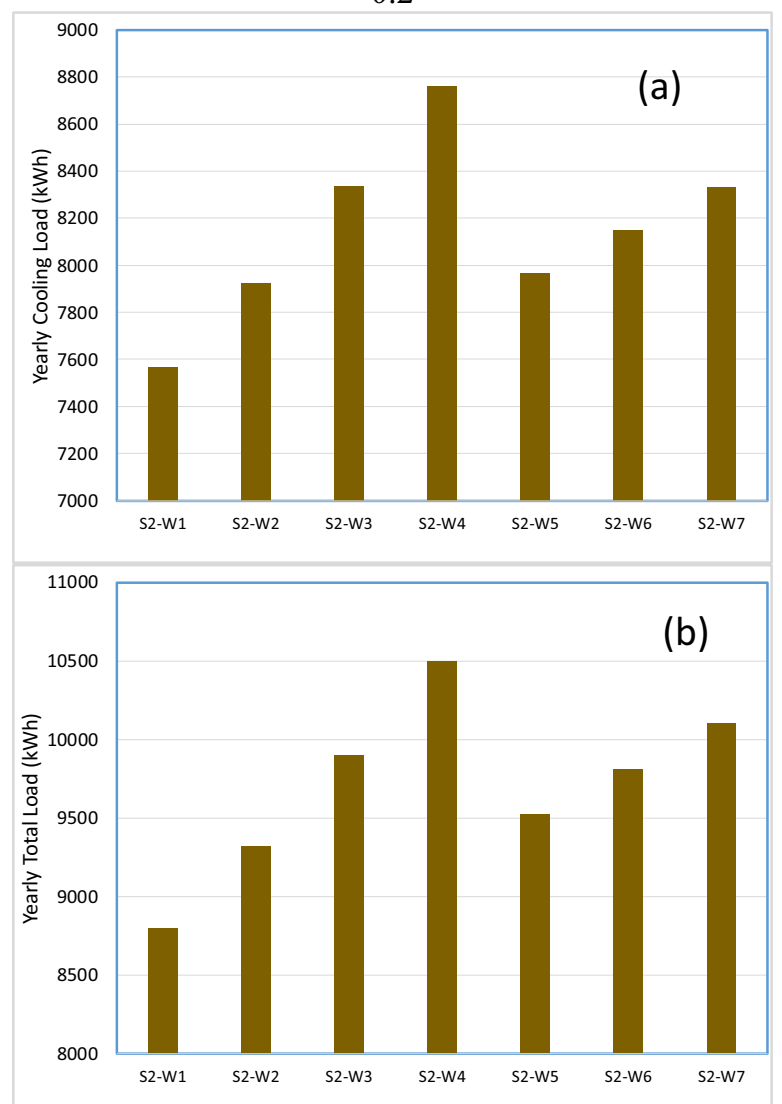

Figure 20. Yearly cooling and total loads when windows in Side 2 for the case of two-zone with roof having $\alpha_{s}=$ 0.2

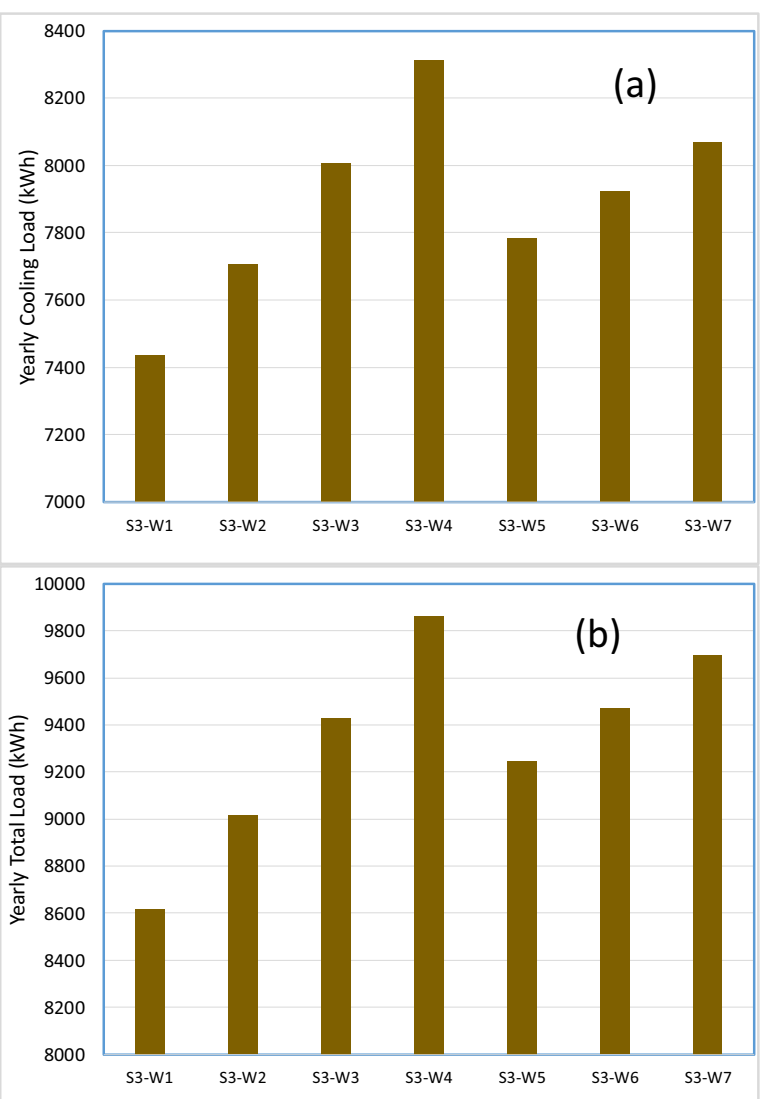

Figure 21. Yearly cooling and total loads when windows in Side 3 for the case of two-zone with roof having $\alpha_{s}=$
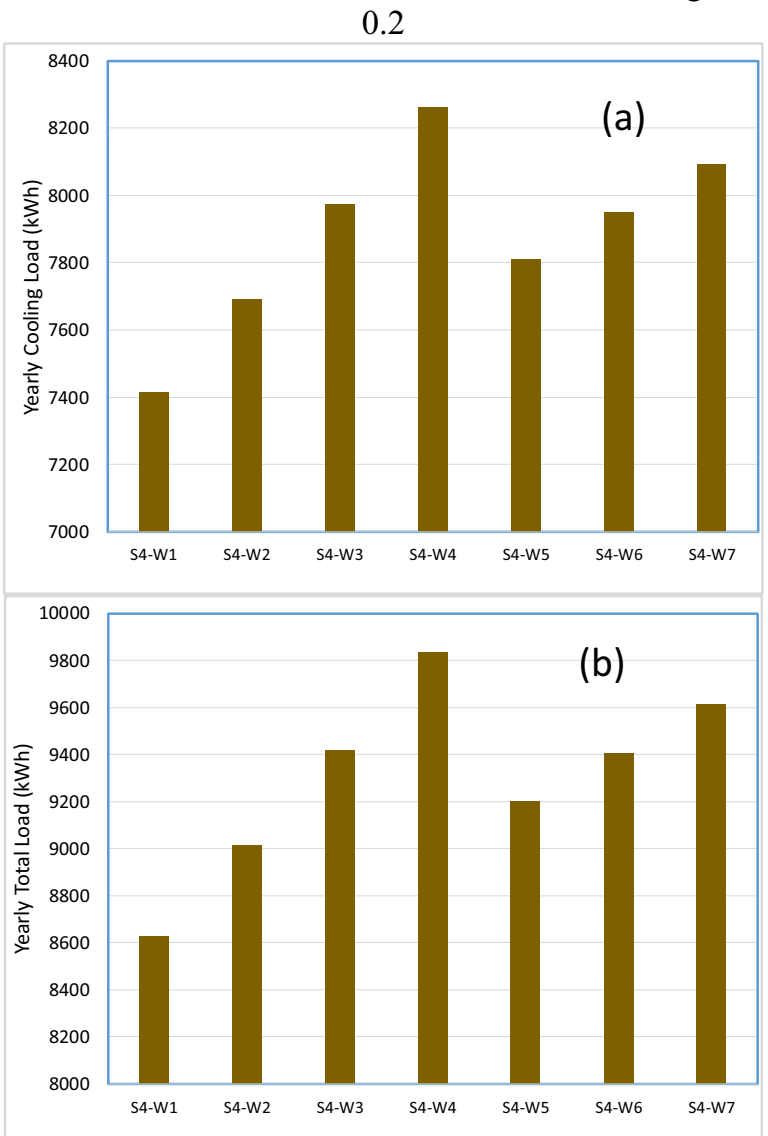

Figure 22. Yearly cooling and total loads when windows in Side 4 for the case of two-zone with roof having $\alpha_{s}=$ 0.2 


\section{Summary and conclusions}

In this study, numerical simulations were conducted to investigate the potential energy savings as results of using white roofing systems of single-zone buildings and two-zone buildings when these buildings were subjected to weather conditions of Saudi Eastern Province. Seven (7) Window-to-Wall Ratios (WWRs) of the main solar oriented window facade were considered in the study, where the ranges of WWR, U-factor, and SHGC were $10 \%-70 \%, \quad 1.71-3.42 \mathrm{~W} /\left(\mathrm{m}^{2} \mathrm{~K}\right), \quad$ and $0.23-0.36$, respectively. Results showed that the months of the highest total energy loads of different wall systems occurred in July and August. However, the months of the lowest total energy loads depended on the cardinal direction of the wall systems. As well, the contributions to the yearly cooling loads, yearly heating loads and yearly total energy loads of different wall systems for the case of single-zone buildings were slightly greater than that for the case of two-zone buildings.

When the windows were located in the four cardinal directions for single-zone buildings and two-zone buildings, the results showed that the window case of $\mathrm{W} 1\left(\mathrm{WWR}=10 \%\right.$, U-factor $=3.42 \mathrm{~W} /\left(\mathrm{m}^{2} \mathrm{~K}\right)$ and SHGC $=0.36$ ) has resulted in the lowest yearly cooling loads and yearly total loads. However, the window case of W4 $\left(\mathrm{WWR}=40 \%\right.$, U-factor $=3.38 \mathrm{~W} /\left(\mathrm{m}^{2} \mathrm{~K}\right)$ and $\mathrm{SHGC}=$ 0.254 ) has resulted in the highest yearly cooling loads and yearly total loads. As well, locating the window in the cardinal direction of side 4 has resulted in the lowest yearly cooling loads and yearly total loads. Whereas, locating the window in the cardinal direction of side 2 has resulted in the highest yearly cooling loads and yearly total loads. Using reflective materials with lower short-wave solar absorption coefficients in the roofing systems have resulted in a decrease in the yearly total energy loads for both single-zone buildings and twozone buildings.

\section{References}

1. Vrachopoulos, M.G., Koukou, M.K., Stavlas, D.G., Stamatopoulos, V.N., Gonidis, A.F., and Kravvaritis, E.D., "Testing reflective insulation for improvement of buildings energy efficiency", Central European Journal of Engineering, 2(1): 8390, 2012, DOI:10.2478/s13531-011-0036-3.

2. European Commission, Green public procurement thermal insulation technical background report. Report for the European Commission - DG Environment by AEA, Harwell, Owner, Editor: European Commission, DG Environment-G2, B1049, Brussels, 2010.

3. Ministry of Electricity and Water, Energy Conservation Program - Code of Practice, MEW, R6, 2nd Ed. (2010).

4. Zirkelbach, D., Schafaczek, B., and Künzel, H., "Long-term hygrothermal performance of green roofs", Eleventh International Conference on Thermal Performance of the Exterior Envelopes of
Whole Buildings XI (Clearwater, FL, USA, December 4-9, 2010).

5. Solecki, W.D, Rosenzweig, C., Parshall, L., Pope, G., Clark, M., Cox, J., et al., "Mitigation of the heat island effect in urban New Jersey", Environ Hazard, 6(1): 39-49, 2005.

6. Ismail, A., Samad, M.H.A., Rahman, A.M.A., "The investigation of green roof and white roof cooling potential on single storey residential building in the Malaysian climate". In: Proceedings of World Academy of Science, Engineering and Technology, vol. 76, 129-137, 2011.

7. Jo, J.H., Carlson, J., Golden, J.S., Bryan, H., "Sustainable urban energy: development of a mesoscale assessment model for solar reflective roof technologies", Energ Policy, 38(12), 7951-7959, 2010.

8. Levinson, R., Akbari, H., Berdahl, P., Wood, K., Skilton, W., Petersheim, J., "A novel technique for the production of cool colored concrete tile and asphalt shingle roofing products", Sol Energ Mater and Sol C, 94(6): 946-954, 2010.

9. Xu, T., Sathaye, J., Akbari, H., Garg, V., Tetali, S., "Quantifying the direct benefits of cool roofs in an urban setting: reduced cooling energy use and lowered greenhouse gas emissions", Build Environ 48, 1-6, 2012.

10. Oleson, K.W., Bonan, G.B., Feddema, J., "Effects of white roofs on urban temperature in a global climate model", Geophys Res Lett, 37(3), art. no. L03701, 2010.

11. Ray, S., and Glicksman, L., "Potential energy savings of various roof technologies", Eleventh International Conference on Thermal Performance of the Exterior Envelopes of Whole Buildings XI (Clearwater, FL, USA, December 4-9, 2010).

12. Urban, B., and Roth, K., Guidelines for Selecting Cool Roofs, U.S. Department of Energy, Energy Efficiency and Renewable Energy, Building Technologies Program, July 2010.

13. Hutchinson, T., "Cool roofing challenging what's cool." $\quad$ Eco-structure. http://www.ecostructure.com/cool-roofing/challenging-whatscool.aspx, visited in May 2017.

14. Desjarlais, A.O., "Self-drying roofs: What?! No dripping!", Proceedings of Thermal Performance of Exterior Envelopes of Buildings VI, Clearwater, Florida, p. 763-773, 1995.

15. Desjarlais, A.O., Petrie, T.W., Childs, P.W., and Atchley, J.A., "Moisture studies of a self-drying roof: Tests in the large-scale climate simulator and results from thermal and hygric models", Proceedings of the Thermal Performance of the Exterior Envelopes of Buildings VII, Clearwater, Florida, p. 41-54, 1998.

16. McHugh, B., Petrick, R., "Chicago's green and garden roofing codes and technology". In: Proceedings of the 2011 international roofing 
symposium, held in Sept. 7-9; 2011. Washington D.C., USA.

17. Durhman, A., Collins, M., McGillis, W.R., "Utilizing green technology and research to assess green roofing benefits". In: Proceedings of the 2011 international roofing symposium, held in Sept. 7-9; 2011. Washington D.C., USA.

18. Bentz, S.P., "Decision-making process for green options in reroofing". In: Proceedings of the 2011 international roofing symposium, held in Sept. 7-9; 2011. Washington D.C., USA.

19. Ennis, M., Kehrer, M., "The effects of roof membrane coloronmoisture accumulation in lowslope commercial roof systems". In: Proceedings of the 2011 international roofing symposium, held in Sept. 7e9; 2011. Washington D.C., USA.

20. Bludau, C., Zirkelbach, D., and Kuenzel, H.M., "Condensation problems in cool roofs", Interface, the Journal of RCI. Vol. XXVII, No.7, pp. 11-16, 2009.

21. Saber, H.H., Swinton, M.C., Kalinger, P., and Paroli, R.M., "Long-term hygrothermal performance of white and black roofs in North American climates", Journal of Building and Environment, 50: 141-154, 2012 , http://dx.doi.org/10.1016/j.buildenv.2011.10.022.

22. Saber, H.H., Swinton, M.C., Kalinger, P., and Paroli, R.M., "Hygrothermal simulations of cool reflective and conventional roofs", 2011 NRCA International Roofing Symposium, Emerging Technologies and Roof System Performance, held in Sept. 7-9, 2011, Washington D.C., USA.

23. Al-ajmi, F.F., and Hanby, V.I., "Simulation of energy consumption for Kuwaiti domestic buildings", Energy and Buildings, 40, 1101-1109, 2008.

24. Saber, H.H., Maref, W., and Hajiah, A.E., Effective R-value of Enclosed Reflective Space for Different Building Applications", Journal of Building Physics, First published online in October 11, 2019, pp. 1-30, https://doi.org/10.1177/1744259119880306.

25. Saber, H.H., and Maref, M., "Energy Performance of Cool Roofs Followed by Development of Practical Design Tool", Journal of Frontiers in Energy Research, 7:122, p. 1-22, November, 2019, https://doi.org/10.3389/fenrg.2019.00122.

26. Saber, H.H., Maref, W., and Hajiah, A.E., "Hygrothermal Performance of Cool Roofs Subjected to Saudi Climates", Journal of Frontiers in Energy Research, doi: 10.3389/fenrg.2019.00039, https://www.frontiersin.org/articles/10.3389/fenrg.2 019.00039/full, 7:39, p. 1-24, 2019.

27. Saber, H.H., Hajiah, A.E., and Maref, M., "Hygrothermal Performance of Cool Roofs Subjected to Hot and Humid Climates, 2019 Buildings XIV International Conference, Clearwater Beach, FL, USA, December 9-12, 2019.
28. Saber H.H., and Hajiah, A.E. 3D Numerical Modeling for Assessing the Energy Performance of Single- and Two-Zone Buildings with and without Phase Change Materials", Gulf Conference on Sustainable Built Environment, GSBEKW-2019, held in March, 10-13, 2019, Kuwait.

29. Hajiah, A.E., and Saber H.H., "Long-Term Energy and Moisture Performance of Reflective and NonReflective Roofing Systems with and without Phase Change Materials under Kuwaiti Climates", Gulf Conference on Sustainable Built Environment, GSBEKW-2019, held in March, 10-13, 2019, Kuwait.

30. ASHRAE Handbook - Applications, chapter 3 commercial and public buildings. Atlanta: American Society of Heating, Refrigerating and Air Conditioning Engineers, Inc.; 2003.

31. Mukhopadhyaya, P., Kumaran, M.K., Lackey, J., Normandin, N., van Reenen, D., Tariku, F., "Hygrothermal properties of exterior claddings, sheathing boards, membranes and insulation materials for building envelope". In: Proceedings of thermal performance of the exterior envelopes of whole buildings X; p. 1-16. Clearwater, FL, December 2-7, 2007.

32. Kumaran, M.K., Lackey, J., Normandin, N., Tariku, F., van Reenen, D. A., thermal and moisture transport property database for common building and insulating materials, Final Report from ASHRAE Research Project 1018-RP, p.1-229, 2004.

33. ANSI/ASHRAE (2004). Standard 140-2004, Standard method of test for the evaluation of building energy analysis computer programs, GA: American Society of Heating, Refrigerating, and Air-Conditioning Engineers, Atlanta, 2004. 